\title{
ODDZIALYWANIE KAPUCYNÓW WARSZAWSKICH NA KOBIETY W DOBIE MIĘDZYPOWSTANIOWEJ (1831-1864)
}

Wydarzenia społeczno-polityczne XIX w. zmieniły rolę kobiety w życiu rodzinnym, społecznym i religijnym. W sytuacji, gdy z powodu walk o niepodległość Rzeczpospolitej zabrakło mężczyzny, ich rolę przejmowały kobiety. To one wpajały młodzieży wartości religijne, moralne, narodowe, a rozmowy prowadzone w kręgach rodzinnych stały się szkołą formacji patriotycznej ${ }^{1}$. Pojawiła się potrzeba mądrej animacji duchowej kobiet, które poświęcały się służbie społecznej w różnorakich formach działalności. W okresie międzypowstaniowym (1831-1864) kapucyni prowadzili stanowe duszpasterstwo kobiet. Mieli w tym względzie swoiste doświadczenie, byli bowiem katechetami na pensjach żeńskich, prowadzili nauczanie domowe, kierowali kobietami w ich działalności charytatywnej. W jednym artykule nie jest możliwe omówienie szczegółowe posług wszystkich kapucynów. Celem niniejszego jest przedstawienie wybitnych postaci i ich pracy na rzecz animacji kobiet. Popularność działalności apostolskiej kapucynów przełamała stereotypowe opinie, że kapucyni to zakon „dla gminu”. W okresie międzypowstaniowym podjęli oni działania duszpasterskie wśród dam - członkiń Stowarzyszenia Żywego Różańca, i opiekunek warszawskiego „Przytuliska”, wśród ziemianek i arystokratek z kręgów Towarzystwa Rolniczego oraz Związku Dobroczynności Patriotycznej Kobiet.

\section{Oddziaływanie patriotyczne}

Kapucyński program duszpasterski został ukierunkowany przez o. Beniamina Szymańskiego na intensywne duszpasterstwo kobiet,

\footnotetext{
${ }^{1}$ Por. E. J a bło ń s k a - D e p t u ła, Trwanie i budowa. Honorat Koźmiński, kapucyn (1829-1916), Warszawa 1986, s. 29-30.
}

„Nasza Przeszłość” t. 131: 2019, s. 43-72. 
szczególnie z warstw wyższych. Świadczy o tym jego bliska współpraca z popowstaniowym Związkiem Dobroczynności Patriotycznej Kobiet i współpraca z Klementyną z Tańskich Hoffmanową. Była ona jedną z pierwszych Polek, które utrzymywały się dzięki własnej pracy. W roku 1825 Hoffmanowa podjęła obowiązek wizytatorki honorowej dwóch warszawskich pensji i szkół żeńskich (pełniła funkcję „,eforki” - Damy Dozoru). Na początku 1828 roku została mianowana wizytatorem wszystkich szkół i pensji dla dziewcząt w Warszawie. Za podstawowy cel swojej epoki oraz za własne posłannictwo społeczne i moralne Tańska uznała zreformowanie wychowania i wykształcenia ówczesnych kobiet ${ }^{2}$. Model wychowawczy Klementyny miał duże znaczenie w życiu społecznym kraju. Przez cały XIX wiek kształtował poglądy na wychowanie młodych kobiet. Propagowała ona ideał kobiety pokornej, delikatnej, skromnej, łagodnej i czułej. Uważała, że kobieta powinna być również aktywna, pracująca, potrafiąca $\mathrm{w}$ razie potrzeby, utrzymać siebie i bliskich. Obok wskazówek dotyczących ogólnych zasad wychowania kobiety, Tańska skupiała swoją uwagę na sprawach edukacji chrześcijańskiej. W podstawowym jej dziele ${ }^{3}$ znalazł się fragment o prawdziwej pobożności. Hoffmanowa wskazywała wartości wyznaczające człowiekowi życie zgodne z nadprzyrodzonym pojmowaniem świata. Zadaniem kobiety jako pierwszej nauczycielki swego potomstwa, było zaszczepianie w nim słowami i przykładem podstaw wiary katolickiej. Nauka kapłana oraz lektura książek religijnych miała tylko ugruntować wiarę przekazaną przez matkę w dzieciństwie. Kobieta spełniała ważną rolę, bo to w jej ręce złożone zostały ziarna wiary, cnót domowych i obywatelskich. Obywatelskość wyznacza kobietom szereg powinności, tj. podtrzymywanie tożsamości narodowej, nauczanie ubogich, miłosierdzie, filantropia. Uznawała wiarę katolicką za podsta-

\footnotetext{
${ }^{2}$ Por. J. M. C y g a n, Beniamin Szymański, kapucyn, biskup podlaski, „Szkice Podlaskie" 5(1996), s. 114; F. J. D u c h n i e w s k i, Z dziejów polskiej Prowincji kapucynów (1810-1921), [w:] W stużbie pokoju i dobra. Jubileusz pięćdziesięciolecia odrodzenia Warszawskiej Prowincji Kapucynów. Księga Pamiątkowa, pr. zbr. pod red. R. P r e j s, Warszawa 2002, s. 48; M. S t a n k i e w i c z - K o p éc, Poglady Klementyny z Tańskich Hoffmanowej 1798-1845 w refleksji uczennic. Zarys zagadnienia, „Studia Pedagogica Ignatiana” 3(2016), s. 105n.

${ }^{3}$ Klementyna z Tańskich Hoffmanowa, Pamiątka po dobrej matce czyli ostatnia jej rada dla córki. Przez młoda Polkę, Warszawa 1819; M. S t a n k i e w i c z - K o p e ć, Poglądy Klementyny z Tańskich Hoffmanowej 1798-1845 w refleksji uczennic. Zarys zagadnienia, s. 109.
} 
wowy kanon wychowania moralnego, traktując ją nie w sposób werbalny, czy czysto zewnętrzny, ale nawołując do głębokiego przeżywania i praktykowania nakazów Ewangelii. Klementyna uważała, że wiara nie polega na odmawianiu pacierzy, na zwiedzaniu kościołów, na rozdawaniu publicznie jałmużny, na surowym upominaniu drugich. Postawa religijna i chrześcijańska przynależna kobiecie opiera się na żywej miłości bliźniego, na ścisłym dopełnianiu obowiązków wobec siebie i drugich, na oddaniu się z pokorą woli Bożej i Jego wyrokom. Życie zgodne z nakazami Dekalogu, bez bigoterii i czynów na pokaz, duchowe przeżywanie spotkań z Bogiem w codziennej pracy stanowiły dla Hoffmanowej kanon wychowania moralnego kobiety ${ }^{4}$.

Penitentka o. Beniamina stała u początków najbardziej śmiałej i nowatorskiej inicjatywy kobiecej powstania listopadowego, jaką było utworzenie samodzielnej patriotyczno-charytatywnej organizacji. Związek Dobroczynności Patriotycznej, zwany później Związkiem Dobroczynności Patriotycznej Warszawianek, został założony 29 grudnia 1830 r., na skromną pamiątkę dnia 29 listopada. Jego organizatorki spotykały się już od pewnego czasu w domu Klementyny z Tańskich Hoffmanowej. Za wzór organizacyjny posłużyć miały patriotyczne kółka kobiece, działające na terenie Prus podczas wojen napoleońskich. Drugie źródło inspiracji stanowiły nagłośnione przez prasę inicjatywy kobiet na prowincji tj. zbiórka kosztowności i pieniędzy wspierających ojczyznę. Napisanie odezwy i statutu uczestniczki zebrania powierzyły Klementynie, wybranej jednogłośnie na przewodniczącą. Nowo powstały Związek stawiał sobie za cel wspomaganie ochotników, opieka nad żonami i dziećmi wojskowych, pielęgnowanie chorych i rannych, zaopatrywanie szpitali i inne uczynki miłosierdzia ${ }^{5}$. W XIX w. do obowiązków każdej chrześcijanki należało pomaganie potrzebującym. Wyróżniało to ziemianki na tle kobiet pochodzących z innych warstw społecz-

\footnotetext{
${ }^{4}$ Por. S. G a w 1 i k, Dziedzictwo pedagogiczne Klementyny z Tańskich Hoffmanowej, Opole 1996, s. 96; H. M a r k i e w i c z o w a, Rodzina i jej wplyw na religijne postawy dzieci $w$ literaturze pedagogicznej: próba zarysu historii, „Studia Theologica Varsaviensia" 1(2000), s. 210; M. S t a n k i e w i c z-K o p éc, Poglady Klementyny z Tańskich Hoffmanowej 1798-1845 w refleksji uczennic. Zarys zagadnienia, s. 110.

${ }^{5}$ Por. A. B a r ań s k a, Kobiety w powstaniu listopadowym 1830-1831, Lublin 1998, s. $157 n$.
} 
nych, a jednocześnie niejako zobowiązywało do dawania dobrego przykładu swoją pobożnością pobliskiej społecznoścí

Przez cały okres powstania listopadowego, a potem po jego upadku, Związek Dobroczynności Patriotycznej utrzymywał bliskie kontakty z o. Beniaminem, który w latach 1830-1831 zyskał w Warszawie niezwykłą popularność ze względu na swe zaangażowanie w działalność charytatywno-patriotyczną. W czasie zrywu listopadowego pełnił obowiązki pielęgniarza w lazarecie i pracował wraz ze swoimi współbraćmi kapucynami przy sypaniu szańców i okopów. Dnia 3 grudnia 1830 roku o. Szymański poświęcił „insygnia wolności”: czerwoną czapkę frygijską lub - jak twierdzą inni - krakuskę. W warszawskim kościele kapucyńskim poświęcone zostały dwa sztandary legionowe. Gwardian tegoż klasztoru (o. Beniamin) zasłużył się w akcji szpitalniczo-charytatywnej. Głosił przy tym „stosowne kazanie”, nawołując do „świętej jedności” i do zapominania urazów ${ }^{7}$. Korzystał wielokrotnie z pomocy Związku, zwłaszcza na polu opieki nad rannymi, kierował też do Klementyny z Tańskich Hoffmanowej swoje penitentki. Jako wizytatorka szkół żeńskich, zwróciła się o pomoc do warszawskich pensji dla dziewcząt. Wśród uczennic powstał nawet rodzaj sekcji czy filii Związku, zaś uczennice szkół wyższych zawiązały nowe dobroczynne towarzystwo Młodych Polek ${ }^{8}$.

Ojciec Beniamin podjął również współpracę z generałową Katarzyną Sowińską, której działalności patriotycznej nadał charakter religijny? Była ona kobietą wielkiego serca i charakteru. Znana z pięknych przymiotów cieszyła się wielkim autorytetem wśród związkowych koleżanek, a wybrana jednomyślnie na przewodniczącą po wyjeździe Hoffmanowej

\footnotetext{
${ }^{6}$ Por. M. M a z a n - J a k u b o w s k a, Kobiety i katolicka kultura religijna $w$ środowisku polskich ziemian i drobnej szlachty na Ziemiach Zabranych w XIX wieku, „Studia Białorutenistyczne" 8(2014), s. 52.

${ }^{7}$ Por. K. B. H o f f m a n, Wielki Tydzień Polaków czyli opis pamiętnych wypadków w Warszawie od dnia 29 listopada do 5 grudnia 1830, Warszawa 1915, s. 38n; J. Z i ó ł e k, Patriotyczna postawa duchowieństwa $w$ czasie powstania 1830-1831 roku, „Roczniki Humanistyczne 2(1980), s. 87.

${ }^{8}$ Por. E. J a b ł o ń s k a - D e p t u ł a, Przystosowanie $i$ opór: Zakony męskie w Królestwie Kongresowym, Warszawa 1983, s. 243. 288; J. M. C y g a n, Beniamin Szymański, kapucyn, biskup podlaski, s. 113; A. B a r a ń s k a, Kobiety w powstaniu listopadowym 1830-1831, s. 163.

${ }^{9}$ Por. J. M. C y g a n, Beniamin Szymański, kapucyn, biskup podlaski, 114; F. J. D u c h n i e w s k i, Z dziejów polskiej Prowincji kapucynów (1810-1921), s. 48.
} 
14 października 1831 r. z Warszawy, całkowicie poświęciła się swoim obowiązkom. Po rozpoczęciu działań wojennych oddała własny dom na lazaret. W pierwszą rocznicę śmierci męża, który poległ 6 września 1831 r. podczas bohaterskiej obrony Woli, Sowińska ślubowała, że poświęci resztę życia na niesienie pomocy cierpiącym, a szczególnie rodakom. Przewodniczyła Związkowi Dobroczynności Patriotycznej Warszawianek, który był pierwszą na ziemiach polskich organizacją czysto kobiecą. Była to organizacja o dobrze przemyślanej strukturze i systemie pracy przystosowanym do potrzeb chwili, skupiająca bardzo dużą jak na swoje czasy liczbę członkiń. Na uwagę zasługuje ścisłe połączenie dwóch elementów: dobroczynności i patriotyzmu ${ }^{10}$. Związek Dobroczynności Patriotycznej Warszawianek zacieśniał współpracę z zaangażowanym w działalność charytatywną o. Beniaminem, który ułatwiał generałowej Sowińskiej załatwianie u rzemieślników warszawskich tanich obstalunków butów i ciżem dla jeńców ${ }^{11}$.

Rezydent rosyjski w Krakowie Zarzycki, który zajmował się między innymi śledzeniem nielegalnej emigracji oficerów polskich z Królestwa napisał raport o buntowniczej działalności „Komitetu Pań Warszawskich” przy udziale o. Beniamina. W lipcu 1832 r. nad Związkiem rozciągnięty został tajny nadzór policyjny. Dochodzenie wykazało, że ,istnieje w Warszawie stowarzyszenie złożone z tutejszych szkodliwych patriotek w zamiarze zbierania funduszów dla emigrantów lub też inne polityczne cele, w sprawie ukrywania wojskowych przed poborem [...] a chociaż nic pewnego w tej mierze nie wykryto, lecz bliskie stosunki Sowińskiej z niektórymi znanymi patriotkami i odbywane u niej sesje dziesięciorga dam nasuwają w tej mierze podejrzenia"12. Zaangażowanie się o. Beniamina w działalność Związku Dobroczynności Patriotycznej sprawiło, że w roku 1835 nie został prowincjałem. W prowincji panowało powszechne przekonanie, że na najbliższej kapitule prowincjałem powinien zostać wybrany o. Beniamin. Kapituła była zapowiedziana na 28 sierpnia do Lubartowa, ale $\mathrm{z}$ powodu owego zaangażowania się

\footnotetext{
${ }^{10}$ Por. A. B a r a ń s k a, Kobiety w powstaniu listopadowym 1830-1831, s. 162, 171n.

${ }^{11}$ Por. A. K r a u s h a r, Generałowa Sowińska i Klementyna Hoffmanowa w czasach powstania listopadowego i po kapitulacji Warszawy. Karta z dziejów „Związku patriotycznego dobroczynności pań polskich" w latach 1831-1833, Lwów 1917, s. 26,30; por. A. B a r a ń s k a, Kobiety w powstaniu listopadowym 1830-1831, s. 320.

12 A. K r a u s har, Generatowa Sowińska $i$ Klementyna Hoffmanowa $w$ czasach powstania listopadowego i po kapitulacji Warszawy, s. 37.
} 
kilka lat wcześniej, spoczęło na nim „czujne oko” rządu, tak że zaledwie otrzymał pozwolenie na wyjazd z Warszawy. Po zasięgnięciu opinii stało się jasne, że na wypadek wyboru i tak nie zostanie zatwierdzony na urząd przez władze carskie Królestwa. W zaistniałej sytuacji o. Beniamin był zmuszony złożyć kapitule pisemną rezygnację z biernego prawa wyborczego ${ }^{13}$. Podobnie szykanowana przez władze była generałowa Sowińska. Na skutek powtarzających się donosów w latach 1835-1837 została internowana w klasztorze mniszek w Łomży. Według relacji Natalii Kickiej, dzięki protekcji przeniesiona ją z warszawskiego więzienia. Po uwolnieniu wróciła do stolicy, gdzie aż do śmierci opiekowała się ubogimi i sierotami, wspomagała więźniów i zesłańców. Zmarła 9 czerwca 1860 r., a jej pogrzeb stał się jedną $\mathrm{z}$ pierwszych manifestacji patriotycznych $\mathrm{w}$ okresie poprzedzającym powstanie styczniowe. W uroczystościach wzięło udział wiele tysięcy mieszkańców stolicy. Zgromadzili się licznie studenci, uczniowie oraz młodzież rzemieślnicza ${ }^{14}$.

Warto zwrócić uwagę na fakt, iż warszawscy kapucyni jeszcze przed powstaniem listopadowym zdobywali poważne doświadczenie w organizowaniu pochówków swoich dobrodziejów. Szczególne znaczenie i walor nowości miał tu fakt, że w poświęconych mowach pogrzebowych kapucyńscy kaznodzieje zaczęli transponować wzorzec pochwały osoby w pewnym sensie zarezerwowany dla wielkich postaci życia narodowego, politycznego, społecznego. Obok dominującego jeszcze w oświeceniu paradygmatu polityczno-militarnego i patriotycznoobywatelskiego, w kapucyńskim kaznodziejstwie okolicznościowym już w pierwszej połowie XIX w. zaczęła tworzyć się przestrzeń dla amplifikacji religijno-społecznego, religijno-środowiskowego i religijnorodzinnego modelu cnoty. Okazją do takich obchodów były pogrzeby kogoś, kogo się określało prawym Polakiem czy Polką. Wystarczyła

\footnotetext{
${ }^{13}$ Por. Acta capituli provincialis Lubartoviae die 28 VIII 1835 celebrandi, [w:] Archiwum Prowincji Warszawskiej w Zakroczymiu, 3-I-3, t. 8; por. F. D u c h n i e w s k i, Polska Prowincja Kapucynów w XIX wieku (1795-1864), [w:] Zakony franciszkańskie w Polsce, pod red J. Kł o c z o w s k i e g o, t. 4, cz. 1, Lublin 1987, s. 60.

14 Por. N. K i c k a, Pamiętniki, wstęp i przypisy J. D u t k i e w i c z, oprac. tekstu T. S z a f r a ń s k i, Warszawa 1972, s. 399n; por. J. K o m a r, Warszawskie manifestacje patriotyczne 1860-1861, Warszawa 1970, s. 11; A. B a rańs k a, Kobiety w powstaniu listopadowym 1830-1831, s. 323; S. K i n i e w i c z, Warszawa w powstaniu styczniowym, Warszawa 1983, s. 58.
} 
najmniejsza aluzja, aby temat kazania „zwekslować” na problematykę narodową. Na przykład mowa pogrzebowa nad trumną siostrzenicy bpa Skórkowskiego stała się okazją do opowiedzenia dziejów biskupa, który tak szlachetnie zapisał się w historii powstania listopadowego. Mogły to być również uroczystości czysto religijne, nawet czysto kapucyńskie, jak wprowadzenie nowych świąt zakonnych, np. sprowadzenie relikwii św. Weroniki przez o. Szymańskiego. Mogła to być także ściśle patriotyczna okazją, jaką było wystawienie mauzoleum króla Jana III Sobieskiego ${ }^{15}$.

Ojciec Beniamin dzięki swemu formatowi intelektualnemu pozyskiwał kontakty z arystokracją stolicy lub mającą w niej rezydencje: Bielińskimi, Czartoryskimi, Grudzińskimi, Krasińskimi, Łubieńskimi, Ostrowskimi, Potockimi oraz bogatym i wpływowym mieszczaństwem, np. Brykczyńskimi, Marchwickimi, Millerami i rodzinami urzędniczymi. Bywał gościem salonów literackich u Wilkońskich. Czytamy, że w owych salonach bywali ,mistrzowie pędzla i dłuta, mistrzowie tonów, artyści dramatyczni i o. Beniamin Szymański, przełożony kapucynów, a późniejszy biskup podlaski" ". Salony odgrywały dość istotną rolę jako miejsca przekazywania wiadomości wojskowych i politycznych, stąd też w kręgu uczestników życia towarzyskiego osoby uchodzące za dobrze poinformowane zyskiwały możliwość skutecznego wpływu na opinię. Zgromadzenia bywały szczególnie tłumne w momentach ważnych wydarzeń ${ }^{17}$.

Osobista znajomość o. Beniamina z generałem Wincentym Krasińskim sprawiała, że bywał w domu jego syna Zygmunta, któremu towarzyszył duchowo w przeżywaniu „dziwnego rodzaju cierpień”. Opowiadał o tym Natalii Kickiej ${ }^{18}$. Wdowa po generale Ludwiku Kic-

15 Por. E. Jabłońska-D e ptuła, Zaangażowanie patriotyczne kapucynów, [w:] Trzysta lat kapucynów w Polsce 1681-1981. Materiały z Sympozjum w Zakroczymiu 27-29 październik 1981, Zakroczym-Warszawa-Kraków 1987, s. 239; M. B r z o z o w s k i, Działalność kaznodziejsko-misyjna kapucynów, [w:] Trzysta lat kapucynów w Polsce 1681-1981, s. 233; A. K a p u ś c i ń s k a, „Boska teoria socjalna, na której postęp ludzkości zawisł”. Prokop Leszczyński (1812-1895) i literacki projekt kordialno-ultramontański, Poznań 2015, s. 252n.

${ }_{16} \mathrm{P}$. W i $1 \mathrm{k}$ ón s k a, Wspomnienia o życiu towarzyskim $w$ Warszawie, Warszawa 1959, s. 82-83; I. B a r a n o w s k i, Pamiętniki (1840-1860), Poznań 1923, s. 153; por. F. J. D u c h n i e w s k i, Z dziejów polskiej Prowincji kapucynów (1810-1921), s. 47. ${ }^{17}$ Por. A. B a r a ń s k a, Kobiety w powstaniu listopadowym 1830-1831, s. 96.

${ }^{18}$ N. K i c k a, Pamiętniki, s. 126; por. J. M. C y g a n, Beniamin Szymański, kapucyn, biskup podlaski, s. 114. 
kim, utrzymywała z o. Beniaminem bliskie relacje. Angażowała się w powstanie listopadowe. Symbolem poparcia dla powstania stała się już od pierwszego dnia „kokarda narodowa”, początkowo najczęściej biała, niekiedy trójkolorowa na wzór francuski lub biało-czerwona. Przypinali je zarówno wojskowi, jak i osoby cywilne. Damy nosiły ją przy kapeluszach, matki wiązały dzieciom. Przygotowaniem, a często także uroczystym wręczaniem kokard zajmowały się warszawianki wszystkich stanów, od arystokratek do służby. Natalia Kicka z pomocą siostry i służących pocięła na kokardy dla żołnierzy atłasowe ogony do sukien noszonych na balach dworskich. Warszawiacy dawali w ten sposób wyraz swoim uczuciom patriotycznym ${ }^{19}$. Relacje $\mathrm{z}$ okresu bitew pod Wawrem i Grochowem zgodnie potwierdzają, że warszawskie kościoły napełnione były w tych dniach tłumem modlących się kobiet. Natalia Kicka wyznawała później, że szukając ulgi „szłam z kościoła do kościoła, żebrałam miłosierdzia Bożego klęcząc, aż póki ostatnia Msza święta nie zostanie odprawiona" ${ }^{\text {,20 }}$.

W trudnych momentach życiowych, których nie brakowało w XIXwiecznych realiach pod zaborem rosyjskim, wiara katolicka pomagała kobietom przerwać ich prywatne tragedie. Znajdowały dzięki niej ukojenie w cierpieniu i spokój ducha ${ }^{21}$. W następnych miesiącach warszawianki uczestniczyły licznie zarówno w uroczystościach religijnych organizowanych przez czynniki rządowe, jak i w rozmaitych nabożeństwach (dziękczynnych, błagalnych, w intencji wojska, w intencji poległych) urządzonych staraniem Towarzystwa Patriotycznego. Udział w nabożeństwach patriotycznych wpływał, zwłaszcza u kobiet, na ożywienie życia religijnego a kaznodzieje kapucyńscy stawali się nauczycielami narodowej historii ${ }^{22}$.

Beniamin Szymański, będąc biskupem podlaskim nadal utrzymywał kontakty z Natalią Kicką. Ona to zaprojektowała witraże do jego

\footnotetext{
${ }^{19}$ Por. N. K i c k a, Pamiętniki, s. 386. 556; por. A. B a r a ń s k a, Kobiety w powstaniu listopadowym 1830-1831, s. 33.

${ }^{20}$ N. K i c k a, Pamiętniki, s. 259.

${ }^{21}$ Por. M. M a z a n - J a k u b o w s k a, Kobiety i katolicka kultura religijna $w$ środowisku polskich ziemian i drobnej szlachty na Ziemiach Zabranych w XIX wieku, s. 53. ${ }^{22}$ Por. E. J a błoń sk a - D e p t u ła, Życie religijne $w$ powstaniu listopadowym, „Novum” 1978, nr. 5, s. 70-105; nr. 6, s. 74-101; M. M a z a n - J a k u b o w s k a, Kobiety $i$ katolicka kultura religijna $w$ środowisku polskich ziemian i drobnej szlachty na Ziemiach Zabranych w XIX wieku, s. 56;.
} 
katedry w Janowie Podlaskim. Oprócz tego, że powszechnym zajęciem w XIX w. było szycie ubrań dla ubogich przez damy pochodzenia ziemiańsko-szlacheckiego, podejmowały się one również sporządzania darów własnej roboty na rzecz kościołów. Zaangażowanie w tym zakresie świadczyło o pobożności oraz o dobrym sercu. Biskup Beniamin wyczulony na piękno kościołów, zwracając się w słowie pasterskim do kapłanów, zachęcał ich nie tylko do świętości życia, ale i do troski o obiekty sakralne i ich wyposażenie ${ }^{23}$.

Oddziaływanie o. Beniamina sięgało daleko poprzez duszpasterstwo kobiet. Już jako katecheta wychował całe pokolenie pobożnych Polek. Pojawił się nowy wzorzec Polki-patriotki, dostosowany do sytuacji Królestwa po upadku powstania listopadowego. Rozwinęła go wkrótce publicystyka i poezja. Polskie matki miały teraz przede wszystkim wychowywać wartościowych obywateli. Częstym sposobem okazywania uczuć patriotycznych w połączeniu z religijną symboliką była żałoba noszona przez kobiety po śmierci polskich bohaterów narodowych, poległych podczas walk i powstań. Przywdziewały one czarne stroje i nosiły przy sobie pamiątki odnoszące się do tych wydarzeń na znak solidarności z cierpieniem całego narodu. Model Polki-żałobnicy: „Gdy w więzach jęczy naród nasz cały, jeden mi tylko przystoi strój - Czarna sukienka!” (K. Gaszyński), wiązał się z hasłem bojkotu „najemników” w życiu prywatnym i towarzyskim. Popowstaniowa satyra ostro potępiała kobiety występujące na balach i wieczorkach z udziałem Rosjan. Nawet młode dziewczęta nosiły żałobę, aby w ten sposób upamiętnić polskich patriotów i oddać im cześć. Wzorem dla nich była matka, która decydowała o tym, jak mają być ubrane jej córki. Od dzieciństwa dbała o podtrzymywanie pamięci w świadomości dzieci o ludziach zasłużonych dla ojczyzny ${ }^{24}$.

${ }^{23}$ Por. N. K i c k a, Pamiętniki, s. 584; por. J. S k o ro dzi u k, Janów Podlaski rezydencja biskupów, „Szkice Podlaski” 13(2005), s. 24; P. A l e k s a n d r o w i c z, Diecezja Siedlecka czyli Podlaska (1818-1968), Siedlce 1971, s. 98; P. D r a g a n, Piotr Paweł Beniamin Szymański biskup podlaski w świetle własnych listów pasterskich, „Wiadomości Diecezji Podlaskiej” (1931) nr. 10-12, s. 420; M. M a z a n J a k u b o w s k a, Kobiety $i$ katolicka kultura religijna $w$ środowisku polskich ziemian $i$ drobnej szlachty na Ziemiach Zabranych w XIX wieku, s. 52.

24 Por. J. M. Cygan, Beniamin Szymański, kapucyn, biskup podlaski, s. 114; A. B a r a ń s k a, Kobiety w powstaniu listopadowym 1830-1831, s. 324n. 


\section{Troska o podlaską wieś}

Beniamin Szymański jako biskup podlaski był bardzo nowatorski. Do jego nowego posługiwania dobrze przystawał ideał „duszpasterza patrioty", który wcześniej przyświecał mu w kierowaniu własnym zakonem i jego pracami duszpasterskimi. W wielu zarządzeniach wyprzedził diecezje o wiekowych tradycjach, inicjując nowe formy kultu i pracując nad pogłębieniem dotąd praktykowanych. Sprowadził siostry felicjanki do posługiwania wiernym $\mathrm{w}$ różnych wiejskich parafiach $^{25}$. Siostry pojawiły się w momencie, kiedy nie powiódł się zamysł przeszczepienia na Podlasie sióstr służebniczek założonych przez Edmunda Bojanowskiego. Przyjaciel kapucynów - Ludwik Górski zaangażował siostry felicjanki do Ceranowa, swego majątku na Podlasiu. Do pertraktacji z siostrami felicjankami powołano Komitet Towarzystwa Rolniczego. Ponieważ delegacja tego Komitetu nie mogła zdecydować się na zawarcie definitywnej umowy z felicjankami, Ludwik Górski poczynił eksperyment w swoim majątku. Miał on przekonać innych ziemian o pożyteczności pracy sióstr zakonnych nad kobietami wiejskimi i w pracy z dziećmi. Czynnikiem bardzo ważnym, a może nawet decydującym, który pobudzał Ludwika Górskiego do wysuwania kandydatury sióstr felicjanek, był fakt, że były formowane i pracowały pod kierunkiem kapucynów. Oparcie całego przedsięwzięcia na Zakonie Kapucynów dawało Górskiemu pewność, że ochroniarki, uformowane przez nich duchowo, będą raczej czynnikiem łagodzącym w istniejących konfliktach między wsią a dworem ${ }^{26}$.

Celem pracy sióstr felicjanek na wsi podlaskiej była praca ochroniarska-oświatowo-charytatywna. Dla większego zachęcenia ziemiaństwa diecezji podlaskiej do pójścia $\mathrm{w}$ ślady właścicieli Ceranowa, bp. Beniamin Szymański wprowadził siostry specjalnym listem, w którym nawiązując do sprawozdania o. Aniceta Sierakowskiego z przeprowadzonych misji w Sterdyni na Podlasiu. Jednym z powodu osadzenia tychże sióstr, była słaba znajomość zasad moralności chrześcijańskiej wśród młodego pokolenia wsi. Powstałe z inicjatywy Andrzeja hr. Zamojskiego Towarzystwo Rolnicze obok reform społecznych, zakładało podniesienie poziomu umysłowego oraz poprawę bytu ma-

\footnotetext{
${ }^{25}$ Por. J. M. C y g a n, Beniamin Szymański, kapucyn, biskup podlaski, s. 115.

${ }^{26}$ Por. M. W e r n e r, O. Honorat Koźmiński. Kapucyn 1829-1916, Poznań-Warszawa 1972, s. 129.
} 
terialnego ludzi wsi. Polska wieś w tym okresie w nikłym stopniu umiała posługiwać się słowem drukowanym. Zarząd Towarzystwa chcąc popchnąc sprawę oświaty, musiał przede wszystkim zatroszczyć się o odpowiedni zespół ludzi. Z pomocą przyszedł biskup podlaski o. Beniamin, który całe przedsięwzięcie poparł swoim autorytetem ${ }^{27}$. W tym czasie kapucyni stali się ośrodkiem odrodzenia religijnego powiązanego z nurtem pracy organicznej - z Towarzystwem Rolniczym, którego prezes, Andrzej hr. Zamoyski, napisał w swych pamiętnikach, że został w Polsce dlatego, ponieważ budowanie społeczeństwa polskiego, organiczne budowanie, uważał za swoją drogę do świętości. Wystawiony przez niego przed kościołem św. Krzyża w Warszawie posąg Chrystusa dźwigającego krzyż, miał być religijnym symbolem pracy organicznej. Generalnym spowiednikiem Towarzystwa Rolniczego był o. Prokop Leszczyński ${ }^{28}$.

Sama ochrona, jak czytamy z Historii Zgromadzenia Sióstr Felicjanek ,była to raczej wiejska szkoła mieszana, do której schodziły się dzieci z całej parafii, tj. z kilku wsi, najmniej po sto dziennie bywało, dziewczęta i chłopcy. Rano nauka trwała do 12, po południu do 4 . Uczyły się czytać, pisać, rachować, a największy nacisk kładło się na katechizm, którego niezmiernie potrzebowały. Praca była olbrzymia, ale wdzięczna; dzieciaki niejedne o suchym, czarnym kawałku chleba chętnie przychodziły, a słuchając pilnie, wiele korzystały. W lecie przychodziły dzieci mniejsze, a nawet i malutkie matki znosiły, same idąc w pole; trzeba je było bawić, nosić, karmić i kołysać. W jesieni i w zimie schodziły się większe i starsze dziewczęta i chłopcy - wtedy była już szkoła kompletna. Po rozejściu się dzieci przychodzili ludzie dorośli, którym się coś pożytecznego czytało"29.

Próbę pośredniego oddziaływania kobiet na rzecz polskiej wsi podjął również o. Prokop Leszczyński. Skontaktował swoją penitentkę Józefę Karską z kilkoma kobietami, które myślały o założeniu zgro-

\footnotetext{
${ }^{27}$ Por. T. F r ę c h o w i c z, Cerkiew greko-katolicka na terenie diecezji podlaskiej za rząów biskupa Beniamina Szymańskiego, Rzym 1981, s. 36n.

28 Por. E. Jabłońska-D e ptuła, Zaangażowanie patriotyczne kapucynów, s. 243; R. B e n d e r, Działalność spoleczna polskich kapucynów w XIX i XX wieku, [w:] Trzysta lat kapucynów w Polsce 1681-1981. Materiały z Sympozjum w Zakroczymiu 27-29 październik 1981, Zakroczym-Warszawa-Kraków 1987, s. 247.

${ }^{29}$ Por. Historia Zgromadzenia Sióstr Felicjanek na podstawie rękopisów, cz. 1, Milwaukee 1924, s. 168 n.
} 
madzenia wychowawczego dla dziewcząt. Projekty utworzenia wspólnoty zakonnej nie zostały zrealizowane, gdyż z powodu fatalnego stanu zdrowia Józefa Karska w 1849 roku opuściła Warszawę. Ojciec Prokop osobiście polecił ją w Rzymie o. Hieronimowi Kajsiewiczowi. Obaj zakonnicy przed wstąpieniem do zakonu brali czynny udział w powstaniu listopadowym i reprezentowali podobny profil formacji duchowej. Józefa Karska uzasadniając pracę wychowawczą przyszłego zgromadzenia, stwierdziła, że wychowanie społeczeństwa polskiego trzeba zacząć od wychowania ziemiaństwa, na którym wobec braku „stanu średniego" na ziemiach polskich spoczywa główna odpowiedzialność za losy narodu. Odrodzenie moralne winno rozpocząć się od kobiet, które posiadają w polskim społeczeństwie wyjątkową pozycję i mają szczególnie szerokie pole oddziaływania. W tych sformułowaniach widać zadania kobiety-ziemianki nakreślone przez kierownictwo o. Prokopa ${ }^{30}$. Jego współpraca i duszpasterstwo Towarzystwa Rolniczego sprawiło, że zebrał w ziemiańskich kręgach sumę pół miliona złotych, którą oferował Józefie Karskiej w ramach organizacji zgromadzenia sióstr niepokalanek, aby powróciła do Królestwa Polskiego i założyła zgromadzenie wychowawcze dla kobiet. Sam wyraził gotowość służenia opieką duchową i wszelkimi potrzebnymi usługami. Był przekonany o bezwzględnej potrzebie pracy dla narodu i miał świadomość roli kobiety w jej oddziaływaniu na chłopów i oficjalistów wiejskich ${ }^{31}$.

\section{Warszawski dom schronienia dla kobiet}

Kapucyni przyczynili się do utworzenia w Warszawie charytatywnej organizacji tzw. Magdalenek. Bolesnym problemem kobiet, jaki pojawił się w XIX wieku, było wśród wielu innych zjawisko prostytucji. Biedne dziewczęta wiejskie przyjeżdżające do stolicy w poszukiwaniu pracy, bez oparcia w osobach bliskich i zabezpieczenia materialnego

\footnotetext{
${ }^{30}$ Por. P. L e s z a c z y ń s k i, Mowa pośmiertna na cześć Ludwiki Diannot, Warszawa 1853.

${ }^{31}$ Por. H. K o ź m iń s k i, Ojciec Prokop Kapucyn, Warszawa 1895, s. 47; por. E. J a bło ń s k a - D e p t u ła, Niepokalanki w polskim trwaniu, Niepokalanów 1993, s. 23, 29, 31; A. K a p u ś c i ń s k a, Recepcja Skargowskiej metody parenetycznej w polskim żywotopisarstwie XIX wieku Prokopa Leszczyńskiego OFMCap (1812-1895) i ultramontańskie źródła „renesansu” hagiografii potrydenckiej, „Acta Universitatis Lodziensis. Folia Literaria Polonica" 3(21)2013, s. 323.
} 
bardzo często stawały się ofiarami niemoralnego życia, co często prowadziło je także do chorób wenerycznych i rozpusty, z której trudno było się im już podnieść. Temu problemowi pragnął wyjść naprzeciw kapucyn - o. Ksawery Kralczyński, który w roku 1850 ułożył „Plan poprawy obyczajów”. W tym dokumencie wyłożył swój projekt walki z niemoralnością kobiet. Pragnął go wydać drukiem i rozpowszechnić w całym Królestwie Polski. Projekt ten prawdopodobnie nigdy nie został zrealizowany, gdyż „Plan poprawy obyczajów” zawierał wiele błędów światopoglądowych, a wprowadzenie jego założeń w życie nie byłoby możliwe. O. Ksawery podjął jeszcze próbę utworzenia instytutu dla upadłych kobiet pokutujących, którego pensjonariuszki miały podlegać surowemu regulaminowi, sprzyjającemu wg koncepcji Kralczyńskiego - rehabilitacji. W porozumieniu z współdziałającymi z nim generałową Aleksandrą Petroffową i hr. Augustową Potocką udało się zrealizować w 1855 r. „Dom Schronienia”, któremu nadał nierealny i pozbawiony roztropności regulamin (z 80 punktów). Jednak i ta inicjatywa upadła, albowiem przeholował w surowości. Napisany bowiem regulamin dla tegoż instytutu zawierał wiele nieżyciowych i utopijnych norm, których podobnie jak Planu nie można było zrealizować. Ostatecznie władze zakonne odsunęły o. Ksawerego od kierowania „Domem Schronienia”. Wiele jednak myśli o. Ksawerego wykorzystano przez powstałe po powstaniu styczniowym zgromadzenie Sióstr Matki Bożej Miłosierdzia ${ }^{32}$.

\section{Działalność charytatywna}

Na organizację działalności dobroczynnej w Warszawie miały wpływ powoływane $\mathrm{z}$ inicjatywy prywatnej stowarzyszenia i towarzystwa. W 1854 r. staraniem Pauliny z hr. Krasińskich Górskiej zostało utworzone Towarzystwo Pań Miłosierdzia św. Wincentego à Paulo. Celem tej organizacji było niesienie pomocy najbiedniejszym rodzinom, w których byli również dotknięci chorobą lub kalectwem. Członkinie dzieliły się na odwiedzające i zasiłkujące. Oprócz wsparcia material-

\footnotetext{
${ }^{32}$ Por. F. D u c h n i e w s k i, Polska Prowincja Kapucynów w XIX wieku (1795-1864), s. 163-166; T e n że, Z dziejów polskiej Prowincji kapucynów (1810-1921), s. 51; A. B a r a n, P. P i a s e c k i, Polskie szkoły duchowości w tysiącletniej historii narodu, [w:] Duchowość przełomu wieku, red. S. U r b ań s k i, M. S z y m u la, Wydawnictwo Uniwersytetu Kardynała Stefana Wyszyńskiego, Warszawa 2000, s. 90-91.
} 
nego członkinie Towarzystwa odwiedzały ubogich, pielęgnowały chorych, umieszczały potrzebujących w zakładach, przytułkach lub na służbie, utrzymywały stały kontakt z podopiecznymi, udzielając im duchowego i moralnego wsparcia. Członkinie Towarzystwa, którego przewodniczącą została założycielka, Paulina z hr. Krasińskich Górska, a jej zastępczynią Hortensja hr. Małachowska, korzystając ze swoich koneksji znajdywały filantropów wśród bogatych przemysłowców. Organizowano zbiórki pieniędzy w kościołach, w czasie kwest wielkanocnych, urządzano koncerty i rauty na rzecz ubogich, przyjmowano dary jednorazowe od osób prywatnych, ponadto czerpano dochody $\mathrm{z}$ rocznych składek członkiń zgromadzenia ${ }^{33}$.

Jedną z członkiń odwiedzających była Zofia Truszkowska, która w swoim posługiwaniu zetknęła się z nędzą społeczną i moralną. Widząc w Warszawie wiele zaniedbanych dzieci i staruszek postanowiła przyjść im z pomocą. Projekt ten przedstawiła o. Honoratowi jako swojemu spowiednikowi prosząc, aby nie odmawiał rad i dopomógł do zrealizowania tego przedsięwzięcia. Inicjatywa Truszkowskiej spotkała się z aprobatą i czynnym zaangażowaniem, który od początku wywierał wpływ na formujący się zakład. Ojciec Beniamin załatwił sprawę urzędowego zatwierdzenia zakładu dobroczynnego, który otrzymał oficjalna nazwę: Przytułek św. Feliksa. Z nominacji Szymańskiego, pośrednio dyrektorem przytułku został o. Honorat. Przytułek św. Feliksa rozwijał się szybko i spełniał pożyteczną rolę w społeczeństwie. Do pracy w nim cięgle zgłaszały się nowe kandydatki, najczęściej penitentki o. Honorata ${ }^{34}$.

Kapucyni warszawscy włączyli się w organizowanie instytucji charytatywnej zwanej „Przytuliskiem”. Jego początki sięgają 1858 r., kiedy to, Franciszka Robaczewska wynajęła na własny koszt na Nowym Mieście niewielki domek, który przeznaczyła dla kobiet nie mających dachu nad głową, pożywienia ani pracy. Dom miał na celu „udzielać czasowego schronienia biednym kobietom, nie mogącym onego znaleźć w razie potrzeby w innych specjalnych zakładach dobroczynnych w Warszawie, jak np. rekonwalescentkom wypuszczo-

\footnotetext{
${ }^{33}$ Por. E. M a z u r, Dobroczynność w Warszawie XIX wieku, Warszawa 1999, s. 28.

${ }^{34}$ Por. M. A. T r u s z k o w s k a, Listy do o. Honorata Koźmińskiego (list 1 z listopada 1854 r.), [w:] Wybór pism, t. II, cz. 1, Rzym 1980, s. 1-3; por. M. H. M a z u r e k, Powstanie i rozwój ukrytych zgromadzeń bt. Honorata Koźmińskiego w latach 1874-1908, oprac. i przygot. do druku H. I. S z u m i ł, Sandomierz 2009, s. 60n.
} 
nym ze szpitali, a jeszcze nie dość silnym do zarobkowania, służącym bez służby i bezpiecznego dla ich obyczajów przytułku, wyszłym $\mathrm{z}$ więzienia po odsiedzeniu kary, rokującym poprawę, którym jednak ze względu na ich przeszłość, trudno znaleźć uczciwe zatrudnienie itp." 35 . Oprócz Feliksy Robaczewskiej inne bogate damy i arystokratki, m.in. Seweryna Jędrzejewicz, Józefa Wolska, które wraz z kapucynem o. Fidelisem Paszkowskim i ks. Wiktorem Ożarowskim tworzyły schronisko $^{36}$. Ojciec Fidelis miał opinię jednego z najbardziej aktywnych działaczy narodowych. Udzielał się jako kaznodzieja, organizator nabożeństw patriotycznych i prowadzący werbunek do oddziałów powstańczych ${ }^{37}$. Wokół Przytuliska zrzeszone były osoby związane z wieloraką działalnością religijną i patriotyczną. Powszechna zgodność co do otwarcia zakładu dobroczynnego tego typu wskazuje, że problem bezdomnych, wychodzących ze szpitali, więzień i pozostających bez pomocy budził zainteresowanie nie tylko pojedynczych osób, lecz był podejmowany w szerszych kręgach. Przewodniczącą była Franciszka Robaczewska, która od 1876-1896 tj. do śmierci była protektorką i opiekunką zakładu. Jej mąż, Feliks Robaczewski służył tej instytucji jako lekarz. Józefa Wolska była kasjerką, zaś sekretarzem - Józef Karpiński. Seweryna Jędrzejewicz była członkiem komitetu ${ }^{38}$.

W schronisku potrzebujące kobiety miały uzyskać pomoc, opiekę, radę $\mathrm{w}$ trudnym położeniu. Przytulisko było pierwszym zakładem, gdzie jedynym warunkiem, jaki postawiono w przyjmowaniu osób,

35 „Kłosy” (1875), nr 509, s. 202; por. E. M a z u r, Dobroczynność w Warszawie XIX wieku, s. 64.

${ }^{36}$ Por. F. J. D u c h n i e w s k i, Z dziejów polskiej Prowincji kapucynów (1810-1921), s. 51; T e n ż e, Polska Prowincja Kapucynów w XIX wieku (1795-1864), s. 161.

${ }^{37}$ Por. E. J a błoń s k a - D e p t u ła, J. G a w r y s i a k o w a, Materiaty do zaangażowania patriotycznego zakonów męskich w Królestwie Polskim w latach 1861-1864, [w:] Materiaty do historii zgromadzeń zakonnych na ziemiach polskich $w$ XIX i na początku XX wieku, red. H. D y ląg o w a [i in.], Lublin 1976, s. 143; R. P rej s, Kapucyni Prowincji Polskiej $w$ rewolucji moralnej $i$ powstaniu styczniowym, [w:] Życie zakonne $w$ Królestwie Polskim w latach 1832-1864, red. W. G r a c z y k, J. M. M a r s z a 1 s k a, Kraków 2015, s. 133n.

${ }^{38}$ Por. J. N a le p a, „Przytulisko” warszawskie w latach 1858-1920, mps, Biblioteka Katolickiego Uniwersytetu Lubelskiego, 1967, s. 16; L. C z e r m i ń s k a, Duchowość Sióstr Franciszkanek od Cierpiacych. Studium na podstawie dokumentów Zgromadzenia, Łódź 2009, s. 59. 
do tegoż schronienia, było jego przeznaczenie wyłącznie dla kobiet. W 1860 roku było w Przytulisku ok. 40 pensjonariuszek, dla których o. Fidelis Paszkowski przeprowadził rekolekcje wielkopostne ${ }^{39}$.

Przeniesione z ul. Nowe Miasto na ul. Wilczą Przytuliskiem, prowincjał kapucynów o. Prokop Leszczyński oddał w opiekę felicjankom. Chociaż wyraziły one zgodę na objęcie zakładu, jednak represje popowstaniowe i związana $\mathrm{z}$ nimi kasata zakonu udaremniła realizację zamierzenia. Trzeba zaznaczyć, że od początku istnienia zakładu pojawia się w jego historii osoba o. Honorata. W roku 1859 poproszono go, by opiekował się Przytuliskiem. Koźmiński interesował się zakładem i miał wpływ na jego działalność także po kasacie klasztoru warszawskiego i internowaniu kapucynów do Zakroczymia w 1864 roku. Należy podkreślić, że z chwilą zaistnienia przytułku zaczęto szukać dla niego „opieki zewnętrznej”, której podjęłaby się instytucja o podobnym profilu działalności, akceptowana przez władze zaborcze. Połączenie zakładu z taką instytucją dawało możliwość legalnego istnienia i podstawę prawną funkcjonowania Przytuliska. Dnia 29 grudnia 1858 roku przytułek zastał afiliowany do Bractwa św. Wincentego á Paulo. W dwa lata później Bractwo zrezygnowało z patronatu nad zakładem, który w tej sytuacji pozostał bez prawnych podstaw działania. W roku 1868 Rada Główna Opiekuńcza oddała Przytulisko pod opiekę Warszawskiemu Towarzystwu Dobroczynności ${ }^{40}$.

Jedną z popularniejszych form opieki nad dziećmi prowadzoną przez Warszawskie Towarzystwo Dobroczynności były ochrony. Pierwsza powstała w 1839 r. z inicjatywy kupca, Teofila Janikowskiego i pedagoga-filantropa Stanisława Jachowicza. Z tym ostatnim współpracował na pensji p. Brzezińskiej-Guérin, o. Honorat, spełniając obowiązki prefekta. Obydwaj nauczyciele wszczepiali młodzieży ideały narodowe,

${ }^{39}$ Por. F. J. D u c h n i e w s k i, Z dziejów polskiej Prowincji kapucynów (1810-1921), s. 51; T e nże, Polska Prowincja Kapucynów w XIX wieku (1795-1864), s. 162; L. C z e r m i ń s k a, Duchowość Sióstr Franciszkanek od Cierpiących, s. 61.

${ }^{40}$ Por. K. G r u s z c z y ń s k a, Historia Zgromadzenia Sióstr Franciszkanek od Cierpiacych (1905-1923), C.I, T. I/27, mps, [w:] Archiwum Franciszkanek od Cierpiących w Warszawie, s. 3. 4-5; Życiorys śp. Kazimiery Gruszczyńskiej, Założycielki i długoletniej Prezeski „Towarzystwa Pielęgnowania Chorych Świętego Józefa - Przytulisko" w Warszawie, C. I, T. II/91, mps, [w:] Archiwum Franciszkanek od Cierpiących w Warszawie, s. 21; F. J. D u c h n i e w s k i, Z dziejów polskiej Prowincji kapucynów (1810-1921), s. 51; T e n ż e, Polska Prowincja Kapucynów w XIX wieku (1795-1864), s. $161-164$. 
znajomość dziejów ojczystych i literatury. Z pensji wyszły pierwsze polskie pisarki jak Eleonora Ziemięcka i Narcyza Żmichowska. One to na łamach czasopisma „Pierwiosnek” wyrażały poglądy na temat roli kobiety w społeczeństwie. Jachowicz starał się poznawać warunki bytowe ówczesnych rodzin, miał kontakty z ubogą młodzieżą robotniczą, pomagał wszelkiej nędzy, a zwłaszcza współczuł z dolą sierocą. W 1859 roku istniało w Warszawie już siedem ochron, dwoma $\mathrm{z}$ nich kierował Stanisław Jachowicz. Ochrony miały na celu ,nie uczyć, ale zajęć wychowańców w sposób łatwy i przyjemny przez dzień cały, wdrażać pierwsze pojęcia, przez zabawę, nauczyć poznawania liter i pierwszych początków czytania, wpłynąć na etyczną stronę duszy

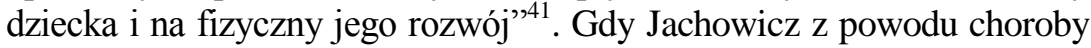
porzucił pracę pedagogiczną, o. Honorat pocieszał go w cierpieniu, uczył religii jego dzieci i prowadził ze starym pedagogiem długie rozmowy. Dzięki tym spotkaniom zapoznał się o. Honorat $\mathrm{z}$ problemami pedagogii i lepiej rozumiał ówczesne potrzeby społeczne, zwłaszcza opieki nad młodzieżą żeńską. Wiele pomysłów od niego wziął do późniejszej działalności przy organizowaniu pracy zgromadzeń zakonnych życia ukrytego. Jachowicz należał do radykalnego Towarzystwa Patriotycznego, a w 1831 roku przy poparciu Joachima Lelewela założył Towarzystwo Wychowania Dzieci po Poległych Rycerzach, którego głównym celem była działalność na rzecz biednych i osieroconych dzieci. Sam przeznaczał na te cele dochody z własnych wydawnictw. Apelował o dobroczynności składek szczególnie do matek polskich. Kierował powstałym w 1829 r. w Warszawie Zakład dla Nieletnich Zaniedbanych Moralnie. Po rozwiązaniu Zakładu, w ramach działalności Warszawskiego Towarzystwa Dobroczynności, założył Szkółkę dla Sierot, kontynuującą działalność opiekuńczą, rozpoczętą w czasie powstania listopadowego. Dzięki inicjatywie prof. Fryderyka Skarbka i zbieranym głównie przez Jachowicza datkom, udało się zgromadzić duży fundusz i wystawić nowoczesny „Dom Sierot i Ochrony dla Małych Dzieci” w Warszawie ${ }^{42}$.

\footnotetext{
${ }^{41}$ E. M a z u r, Dobroczynność w Warszawie XIX wieku, s. 86; M. W e r n e r, O. Honorat Koźmiński. Kapucyn 1829-1916, s. 70; J. F a 1 k o w s k a, Przeciw marzycielstwu. Działalność edukacyjna Anastazji z Jełowickich Dzieduszyckiej, Toruń 2014, s. 8.

42 Por. L. P a w e le c, Stanisław Jachowicz (1796-1857), „Nauczyciel i Szkoła” 3-4(2003), s. 323n; M. W e r n e r, O. Honorat Koźmiński kapucyn 1829-1916, s. 71n.
} 
W połowie XIX wieku w Warszawie zaczął pojawiać się problem nieślubnych dzieci. Najczęściej na samotne macierzyństwo nastawione były służące, młode kobiety przybywające do stolicy w poszukiwaniu pracy i nie mające oparcia. Zdarzało się, że samotne matki porzucały dzieci ${ }^{43}$. Organizowane ochrony przeznaczone były dla dzieci pozbawionych opieki. Finansowały je bardzo często osoby prywatne, znane z działalności filantropijnej, jak np. związane z kapucynami rodziny hrabiów Przeździeckich, hrabiego Tomasza ordynata Zamoyskiego $^{44}$. Za radą o. Prokopa Leszczyńskiego, Ksawery i Julia Pusłowscy założyli nie tylko kościół i dom dla księży emerytów ${ }^{45}$, ale urzędowym aktem darowizny przeznaczyli teren instytutowi moralnie zaniedbanych dzieci. Zbudowano dla „Domu Poprawy” specjalny gmach. W 1869 r. Zakład otrzymał nazwę Instytutu Moralnej Poprawy Dzieci. Akcję opieki nad dzieckiem kontynuowały zgromadzenia założone przez o. Honorata ${ }^{46}$.

W 1885 r. powstało Towarzystwo Opieki nad Ubogimi Matkami oraz ich Dziećmi, które zajmowało się udzielaniem pomocy zamężnym i niezamężnym ciężarnym kobietom, znajdującym się w trudnych warunkach materialnych. Jego organizatorkami były zaprzyjaźnione z kapucynami Julia hr. Branicka i Julia Górska. Starano się także zapewnić lepszą przyszłość niechcianym przez nie niemowlętom, wyszukując za odpłatnością zastępcze rodziny i mamki oraz kontrolując sprawowaną nad dziećmi opiekę. Ogólne fundusze przeznaczone na rozwój Towarzystwa i utrzymanie przytułku, gromadzone były z procentów od posiadanego już kapitału, rocznych składek członków, darowizn, dochodów z koncertów, odczytów i widowisk. Zarząd Towarzystwa składał się z Rady Opiekuńczej i Komitetu Gospodarczego. Przewodniczącą Rady Opiekuńczej została Hortensja hr. Małachowska. Do tejże rady wchodzili również: Julia Górska, Maria Łempicka, Ludwik

\footnotetext{
${ }^{43}$ Por. S. K i n i e w i c z, Warszawa w latach 1795-1914, Warszawa 1976, s. 142.

${ }^{44}$ Por. E. M a z u r, Dobroczynność w Warszawie XIX wieku, s. 87.

${ }^{45}$ Por. H. K o ź m iń s k i, Ojciec Prokop, s. 47; por. A. K a p u ś c i ń s k a, Recepcja Skargowskiej metody parenetycznej w polskim żywotopisarstwie XIX wieku Prokopa Leszczyńskiego OFMCap (1812-1895) i ultramontańskie źródła „renesansu” hagiografii potrydenckiej, s. 321n.

${ }^{46}$ Por. E. M a z u r, Dobroczynność w Warszawie XIX wieku, s. 96; M. W ó j c i k, Zgromadzenie Sióstr Stużek NMP Niepokalanej. Powstanie, rozwój i działalność w latach 1878-1918, Poznań 1978, s. 223.
} 
Górski, Tomasz hr. Zamoyski. Komitet Gospodarczy stanowili m.in.: Maria Wrotnowska, Feliks hr. Grabowski ${ }^{47}$.

\section{Animacja tercjarstwa franciszkańskiego}

Kapucyni, mając ugruntowaną pozycję w duszpasterstwie, mogli ukierunkować swą działalność duszpasterską na tory społeczne. Szczególnie aktywnym ruchem społeczno-religijnym, angażującym tysiące kobiet na ziemiach polskich w połowie XIX wieku był III Zakon św. Franciszka z Asyżu. Kapucyni wznowili przede wszystkim nową formę pracy nad III Zakonem, nadając mu charakter wspólnotowy, a tercjarstwo dzięki inicjatywom o. Honorata zorganizowało się w kongregację. Wyeksponowano dwa główne założenia: pogłębienie życia duchowego i prowadzenie działalności społeczno-charytatywnej. W celu utrzymania właściwego poziomu duchowego, o. Honorat wprowadził zebrania w każdą pierwszą niedzielę miesiąca, połączone $\mathrm{z}$ wyjaśnianiem Reguły, którym sam przewodniczył. Na zebraniach wręczano profeskom patent przynależności do III Zakonu, wybierano także zarząa kongregacji (przełożoną, mistrzynię, sekretarkę, infirmerkę, zelatorki, dyskretki i wizytatorki), który obowiązany był do składania sprawozdań ze swej działalności ${ }^{48}$.

Kongregacja tercjarska łączyła przedstawicielki wszystkich warstw społecznych. W księdze profesek możemy zauważyć różnorodność sytuacji społecznej ówczesnych tercjarek: Joanna Kosmowska, panna, mieszkała przy ojcu; Felicja Babska, utrzymywała się z pracy własnych rąk; Marianna Kobylańska była służącą; Joanna Żórawska doktorową; Marta Wentzel - wdową, którą opiekowała się rodzina; Julia Kosmowska - zamężną urzędniczką; Teresa Brzezińska - kierowniczką pensji dla dziewcząt. Na innych stronicach występują obok siebie guwernantki, kupcowe, służące, szwaczki, pracownice magazynów. Jest profesorowa, szewcowa, dozorczyni i posługaczka. Są kobiety zarabiające lekcjami, żyjące $\mathrm{z}$ jałmużny lub z własnych fundu-

\footnotetext{
${ }^{47}$ Por. E. M a z u r, Dobroczynność w Warszawie XIX wieku, s. 31.

${ }^{48}$ Por. F. J. D u c h n i e w s k i, Z dziejów polskiej Prowincji kapucynów (1810-1921), s. 48; M. H. M a z u re k, Powstanie i rozwój ukrytych zgromadzeń bt. Honorata Koźmińskiego w latach 1874-1908, s. 59; D. O 1 s z e w s k i, Postawy spoleczno-religijne kobiet $w$ Królestwie Polskim w drugiej połowie XIX wieku, [w:] Kobieta i kultura religijna. Specyficzne cechy religijności kobiet $w$ Polsce, red. J. H off, Rzeszów 2006, s. 17; M. C i e re s z k o, Kobieta oddana Bogu - obraz zakonnicy $w$ polskiej prozie narracyjnej II połowy XIX wieku, „Prace Literaturoznawcze” 3(2015), s. 210.
} 
szy, jest fryzjerka, brązowniczka i farbiarka. Wszystkie te kobiety, każda na swój sposób, włączyły się również w akcję dobroczynną prowadzoną w ich środowisku ${ }^{49}$.

Łączenie osób różnego stanu w jednej rodzinie tercjarskiej miało swoje dobre strony, ale niosło za sobą też pewne braki. Kobiety z wyższym wykształceniem potrzebowały innych treści duchowych niż analfabetki. Należały do III Zakonu osoby o różnym poziomie duchowym. Koźmiński przekonany o wysokim zadaniu powołania franciszkańskiego osób świeckich, pragnął, by siostry wypełniały regułę jak najściślej. Po kilku latach kierownictwa przekonał się, że jednak niektóre biorą na serio swe zobowiązania, a inne są opieszałe, przyzwyczajone do dyspens i nie podciągające do ideału. Aby tej potrzebie zaradzić, wykorzystał o. Honorat inną formę pobożnych ugrupowań, tzw. żywy różaniec. Stał się on w jego ręku pewnego rodzaju uzupełnieniem tercjarstwa ${ }^{50}$.

\section{6. Żywy Różaniec}

W Warszawie w 1856 roku o. Koźmiński zaprowadził w kręgu młodzieży bogatego mieszczaństwa i arystokracji koła żywego różańca, podzielone na „róże” według przynależności do stanów społecznych. Członkowie kół związani w różę łączyli się modlitwą we wspólnie obranej intencji, odmawiając i rozważając w ciągu miesiąca jedną z piętnastu tajemnic różańca (w skład jednej róży wchodziło 15 osób). Po upływie miesiąca zbierano się razem i wymieniano między sobą tajemnice. Ta forma modlitwy różańcowej powstała we Francji z inicjatywy Marii Pauliny Jaricot około 1826 r., a sześć lat później została zatwierdzona przez papieża Grzegorza XVI. W Warszawie zaprowadził ten sposób odmawiania różańca po raz pierwszy ks. Wiktor Ożarowski, ale dopiero o. Honorat nadał mu nowe formy organizacyjne i wyjątkowe znaczenie w aktywizacji kobiet i duchowego odrodzenia stolicy ${ }^{51}$.

${ }^{49}$ Księga SS. nowicjuszek i profesek 3-go Zakonu S. O. Franciszka Kapucynek Warszawskich 1830-1857, [w:] Archiwum Główne Zgromadzenia Felicjanek, k. 1-6, s. 24; por. M. W e r n e r, O. Honorat Koźmiński. Kapucyn (1829-1916), s. 79n.

${ }^{50}$ Por. M. W e r n e r, O. Honorat Koźmiński. Kapucyn (1829-1916), s. 80n.

51 Por. P. L i t w iń s k i, Ojciec Honorat z Białej, kapucyn, ze słowem wstępnym J. E. ks. Stanisława Galla, cz. 1, Warszawa 1938, s. 28; M. H. M a z u r e k, Powstanie i rozwój ukrytych zgromadzeń bt. Honorata Koźmińskiego w latach 1874-1908, s. 57. 
Koźmiński dostrzegał w różach, obok niewątpliwego znaczenia dewocyjnego, istotny walor społeczny - szansę na tworzenie więzi, konsolidowanie ludzi, pchnięcie ich także w kierunku pracy charytatywnej, oświatowej, opiniotwórczej. Członkinie tego bractwa oprócz zadań modlitewnych miały wyznaczoną konkretną pracę społeczną ${ }^{52}$. Róże były w rękach o. Honorata nową bronią w walce o Królestwo Boże, a równocześnie miały powiązać społeczeństwo rozbite wewnętrznie i zjednoczyć je przez modlitwę i czyn charytatywny. Tęsknota za więzią społeczną była w ówczesnej Warszawie tak wielka, że wkrótce niemal cała stolica powiązała się w koła. Każda grupa zrzeszała osoby w podobnym wieku i mające określone zapatrywania na rozwiązywanie spraw społecznych. Powodowało to, że dzieła o. Honorata z Białej były skuteczne. Pomysł był nad wyraz trafionym i spowodowało żywiołowy wzrost liczby róż stanowych w całym Królestwie. Tym sposobem ruch różańcowy aktywizował i spajał w działaniu dziesiątki tysięcy osób, w ogromnej większości kobiety, przeciwdziałał w zwątpieniu, wskazywał wspólne cele i rozbudowywał więzi międzyludzkie, tak potrzebne $\mathrm{w}$ dobie ucisku i krępowania inicjatyw społecznych przez władze zaborcze ${ }^{53}$.

Aktywizacja religijna kobiet poprzez kapucyńskie kierownictwo duchowe, która pociągnęła za sobą powstanie szeregu dzieł, poszła niejako dwoma torami. Pierwszy -to oddziaływanie na grupy kobiece aspirujące w sposób świadomy do zajęcia nowej pozycji w życiu religijnym i narodowym, a więc przedstawicielki rodzin ziemiańskich, nawet arystokratycznych, a także świata inteligenckiego. Na czele stanęły tu Aleksandra Potocka, Genowefa Pusłowska, Hortensja Małachowska, Paulina Górska, Amelia Łubieńska oraz Elfryda Zamoyska. Siła oddziaływania kapucynów na osoby wywodzące się z elit wynikała $\mathrm{z}$ ich żarliwości religijnej oraz pryncypialności w wymaganiach duszpasterskich, w umiejętności tworzenia więzów osobistych w kierownictwie duchowym. Drugi tor to aktywizacja kobiet $\mathrm{z}$ warstw

\footnotetext{
52 Por. Z. Krat o chwi 1, H. I. S z u mi ł, Kapucyni w świetle pamiętnika Marii z Eubieńskich Górskiej, Warszawa 2001, s. 76-80; F. J. D u c h n i e w s k i, Z dziejów polskiej Prowincji kapucynów (1810-1921), s. 48; J. O d z i e m k o w s k i, Patriota, [w:] Boży człowiek w stużbie ludziom. Bt. Honorat Koźmiński, red. A. D e r d z i u k OFMCap, G. F i 1 i p i u k OFMCap, Lublin 2018, s. 118n.

${ }^{53}$ Por. E. M u ś n i c k a, O. Honorat z Białej Kapucyn, 1829-1916, Jego żywot i dziatalność, t. 1, Kraków 1925, s. 5; M. W e r n e r, O. Honorat Koźmiński. Kapucyn (1829-1916), s. 83; E. J a bło ń s k a - D e p tuła, Trwanie i budowa, s. 62; J. O d z i e m k o w s k i, Patriota, s. 119.
} 
średnich i niższych. Pozycja kobiet z wyższych sfer była ustalona materialnie. Procesy przemian gospodarczych, a w szczególności uprzemysłowienie, zachwianie pozycji materialnej wielu rodzin na skutek licznych represyjnych konfiskat majątków po klęsce powstania listopadowego spowodowały, że liczne grupy kobiet musiały żyć z własnej pracy. W tym okresie zarysowała się potrzeba zintegrowania religijnego tego środowiska. Potrzeba ta płynęła zarówno z odczucia kapucynów, jak i ich penitentek. Walor łączenia ludzi między sobą dawało Stowarzyszenie Żywego Różańca. Oryginalność myśli o. Honorata polegała na tym, że potrafił on zespolić cel dewocyjny ze społecznym i narodowym, przy pomocy róż skonsolidować ludzi między sobą. Każda róża, czyli piętnastka ludzi, była organizmem samoistnym i posiadała wyłonionych ze swego grona prezesa, zelatora i jałmużnika. Zobowiązana była do zajęcia się konkretną pracą na rzecz drugich, czy to charytatywną, czy oświatową ${ }^{54}$.

Wszystkie damy z „róży arystokratycznej” tworzyły zespół bardzo zgrany i w różnych sprawach charytatywnych i narodowych występujący jednolicie. Wymownym tego przykładem był negatywny stosunek pań z arystokracji do dworu Wielkiego Księcia Konstantego. Żadne perswazje i żadne naciski nie były w stanie zmusić ich, by wzięły udział w dworskich przyjęciach ${ }^{55}$.

\section{Aktywność zakonotwórcza}

Ojciec Beniamin Szymański już w połowie XIX w. wystąpił z projektem zgromadzeniotwórczym. Pragnął bowiem przeszczepić na grunt polski niemieckie siostry pasterki, opiekujące się dziewczętami $\mathrm{z}$ marginesu społecznego. Widząc potrzebę istnienia takiego zgromadzenia w Królestwie Polskim, prowadził w 1855 r. w tej sprawie tajną korespondencję z biskupem Monastyru (Westfalia) Jerzym Müllerem o przysłanie sióstr zakonnych żyjących według trzeciej reguły św. Franciszka z Asyżu. Niestety policja carska przejęła listy, zakazując jakichkolwiek starań. Ojciec Beniamin nie zrezygnował z prób, zamierzając wysyłać polskie kandydatki do pasterek niemieckich, aby po

\footnotetext{
${ }^{54}$ Por. P. L i t w iń s k i, Ojciec Honorat z Białej, Kapucyn, s. 28-29; E. J a bło ń s k a - D e p tuła, Trwanie $i$ budowa, s. 34n; K. L e m án s k a, Fenomen ukrytego życia zakonnego na przykładzie zgromadzeń założonych przez o. Honorata Koźmińskiego, Lublin 1995, s. 43.

${ }^{55}$ Por. M. W e r n e r, O. Honorat Koźmiński. Kapucyn (1829-1916), s. 83.
} 
formacji za granicą mogły powrócić do Królestwa i konspiracyjnie przeszczepić swoje zgromadzenie ${ }^{56}$.

Działalność wielu osób przynależących do III Zakonu i Bractwa Żywego Różańca łączyła się z pracą Bractwa św. Wincentego przy kościele księży misjonarzy. Spośród osób czynnych w obydwu ośrodkach wyróżniła się Zofia Truszkowska, penitentka o. Honorata Koźmińskiego. Duchowość jej formowała się w kręgu kapucyńskim. Ojciec Honorat zachęcał Truszkowską i jej cioteczną siostrę Klotyldę Ciechanowską do wstapienia do III Zakonu św. Franciszka. W roku 1854 Zofia założyła przytułek charytatywny w Warszawie na Nowym Mieście. Oprócz podopiecznych zaczęły się tam gromadzić tercjarki kapucyńskie, których opiekunem i kierownikiem duchowym był o. Honorat. Wzrost liczebny pensjonariuszek wymusił przeniesienie zakładu z ul. Kościelnej na ul. Mostową. Znany był pod nazwą „Instytut panny Truszkowskiej”. W dniu 21 listopada 1855 r. o. Honorat poświęcił zakład, a Zofia Truszkowska i Klotylda Ciechanowska specjalnym aktem oddały się na wyłączną służbę Bożą. Zakładem i jego opiekunkami interesowała się tercjarka kapucyńska s. Kunegunda Michalina Rhebinder, która wkrótce przyłączyła się do grona opiekunek. Zakład stale się rozwijał, powiększała się liczba dzieci i staruszek, zgłaszały się nowe tercjarki kapucyńskie. W związku z tym zaistniała konieczność otoczenia zakładu opieką tak ze strony władzy kościelnej, jak również uzyskanie prawnej sankcji ze strony władz rządowych. Wówczas o. Beniamin Szymański, prowincjał kapucynów, wpływowy w szerszych sferach, wyraził zgodę na oficjalne przyjęcie „Zakładu panny Truszkowskiej” pod jurysdykcję kapucynów warszawskich. Przełożoną od 13 kwietnia 1856 r. została s. Kunegunda Rhebinder. Dnia 16 kwietnia 1856 r. o. Beniamin zlecił o. Honoratowi funkcję kierowniczą w formie nadzoru i opieki duchowej ustanawiając go dyrektorem, spowiednikiem i kierownikiem duchowym. Jemu też polecił ułożyć specjalny regulamin życia i pracy w zakładzie. Postarał się też o czasowe zatwierdzenie zakładu u władz rządowych. Ojciec Honorat w 1907 r. pisał do kardynała Dominika Ferrata, że to o. Beniamin założył Zgromadzenie Sióstr św. Feliksa i powierzył mu kierownictwo tegoż zgromadzenia ${ }^{57}$.

\footnotetext{
${ }^{56}$ Por. F. J. D u c h n i e w s k i, Z dziejów polskiej Prowincji kapucynów (1810-1921), s. 49.

${ }^{57}$ Por. H. K o ź m i ń s k i, Do Kardynała Dominika Ferrata, 20 II 1907 r., [w:] Pisma, t. 1, red. H. I. S z u mił przy współpracy G. B a r t o s z e w s k i e g o, Warszawa
} 
W krótkim czasie od swego powstania, zgromadzenie felicjanek kierowane przez o. Honorata, podjęło się odpowiedzialnych prac apostolskich na terenie Warszawy. W roku 1857 bp Beniamin Szymański zlecił felicjankom opiekę nad tercjarkami świeckimi. Dnia 3 stycznia 1859 r. o. Honorat w kapitularzu felicjanek zwołał pierwsze zebranie tercjarek świeckich. Zapowiedział zgromadzonym, że odtąd będą się odbywać pod jego kierunkiem podobne zebrania w każdą pierwszą niedzielę miesiąca dla odnowienia się w pełnieniu praktyk i przywrócenia tercjarstwu pierwotnej gorliwości ${ }^{58}$.

Swoje doświadczenia $\mathrm{z}$ organizowaniem zgromadzeń zakonnych miał o. Leander Lendzian, którego działalność wiąże się z genezą wspólnoty zakonnej sióstr nazaretanek. Urodzony w 1817 roku w Pułtusku, a pochodzący z szlacheckiej rodzinie litewskiej, poświęcił się karierze urzędnika państwowego, a następnie został dyrektorem komisji finansów w Warszawie. Za panowania cara Mikołaja I wprowadzono szpiegowskie metody wśród urzędników państwowych, którym zakazano jakiejkolwiek działalności patriotycznej i zobowiązano do donoszenia na kolegów. Lendzian na skutek oszczerstw znalazł się na liście oskarżonych. Został skazany na siedem lat więzienia. Uwolniony, w roku 1847 przyjął habit zakonny kapucynów. Po skróconych studiach filozoficznych i teologicznych ze względu na swe szerokie wykształcenie humanistyczne został w 1854 roku wyświęcony na kapłana. Zaangażował się w pracę duszpasterską w Warszawie. Pozostający w bliskich kontaktach z rodziną Siedliskich. Znajomość skłoniła Cecylię Siedliską do korzystania ze skutecznych rad w zakresie życia duchowego. Odnaleziona pogoda ducha i odzyskanie zdrowia fizycznego, skłoniły ją do powierzenia roli nauczyciela religii córki Franciszki ${ }^{59}$.

1997, L. 3, s. 42-43; T e n ż e, Wiadomości o zgromadzeniach prowadzacych życie ukryte, s. 9; por. J. R. B a r, Ruch religijny kobiet $w$ XIX wieku na ziemiach polskich, „Collectanea Theologica” 37(1967) fasc. III, s. 172n; M. W e rne r, O. Honorat Koźmiński. Kapucyn (1829-1916), s. 91n.

58 Por. Sprawozdanie z I kapituły tercjarskiej z 3 I 1859, Akta kapituł i wyborów 1859-1864, k. 21, [w:] Archiwum Główne Zgromadzenia Felicjanek w Krakowie; por. J. R. B a r, Ruch religijny kobiet $w$ XIX wieku na ziemiach polskich, s. 174.

${ }^{59}$ Por. A. R i c c i a r d i, Franciszka Siedliska. Matka Maria od Pana Jezusa Dobrego Pasterza. Założycielka Zgromadzenia Sióstr Najśw. Rodziny z Nazaretu, thum. M. Immolata K r a j e w s k a, Władysława Minkiewicz, Rzym 1987, s. 7; E. J a bło ń s ka - D e p tuła, J. Gaw r y s i k ow a, Materiaty do zaangażowania patriotycz- 
Ojciec Leander, znając od wczesnej młodości Franciszkę Siedliską, m.in. przygotowywał ją do Pierwszej Komunii św., której uroczystość odbyła się w warszawskim kościele kapucynów. Lendzian wywarł wpływ na położenie podwalin na powstającą w 1874 r. w Rzymie wspólnotę zakonną sióstr nazaretanek ${ }^{60}$. Przyszła jego założycielka Franciszka Siedliska - przez wiele lat była pod kierownictwem duchowym o. Leandra, początkowo w Warszawie, później w Nowym Mieście n. Pilicą, w Lublinie a końcu w Rzymie. Była świadoma jego wpływu na pierwsze siostry Zgromadzenia (m. Rafaela Lubowidzka i m. Joanna Ziątkiewicz) ${ }^{61}$.

\section{Zakończenie}

Głębokie życie duchowe kobiet oraz kultywowanie tradycji patriotycznych wynikały z ich wiary i z pracy formacyjno-duchowej kapucynów. Zaangażowanie społeczne kobiet i demonstrowanie uczuć religijnych wiązały się z trudnym dla polskiego narodu okresem politycznym. Zaistniała sytuacja sprawiała, że na barkach Polek spoczywała powinność umacniania obecności wiary katolickiej, które wraz z pielęgnowaniem języka ojczystego stanowiło formę samoobrony przed dominującą kulturą prawosławną, wspomaganą przez władze carskie. Pielęgnowanie wiary katolickiej i zaangażowanie patriotyczne prowadziło do silnych więzi duchowych między kobietami i kapucynami. Współpraca prowadziła do powstawania różnorakich organizacji społecznych i dzieł charytatywnych.

nego zakonów męskich w Królestwie Polskim w latach 1861-1864, s. 139; R. P r e j s, Kapucyni Prowincji Polskiej w rewolucji moralnej i powstaniu styczniowym, s. 135.

${ }^{60}$ Por. F. J. D u c h n i e w s k i, Z dziejów polskiej Prowincji kapucynów (1810-1921), s. 50; M. B u d z i a r e k, Kapucyni w Lublinie. Dzieje klasztoru w latach 1721-1864, Warszawa-Lublin 1996, s. 151-155.

${ }^{61}$ Por. A. R i c c i a r d i, Franciszka Siedliska. Matka Maria od Pana Jezusa Dobrego Pasterza. Założycielka Zgromadzenia Sióstr Najśw. Rodziny z Nazaretu, s. 163; M. H. M a z u r e k, Powstanie i rozwój ukrytych zgromadzeń bt. Honorata Koźmińskiego $w$ latach 1874-1908, s. 55. 


\section{Bibliografia}

Acta capituli provincialis Lubartoviae die 28 VIII 1835 celebrandi, [w:] Archiwum Prowincji Warszawskiej w Zakroczymiu, 3-I-3, t. 8.

Aleksandrowicz P., Diecezja Siedlecka czyli Podlaska (1818-1968), Siedlce 1971.

Bar R. J., Ruch religijny kobiet w XIX wieku na ziemiach polskich, „Collectanea Theologica" 37(1967) fasc. III, s. 165-177.

Baran A., Piasecki P., Polskie szkoły duchowości w tysiącletniej historii narodu, [w:] Duchowość przełomu wieku, red. S. Urbański, M. Szymula, Wydawnictwo Uniwersytetu Kardynała Stefana Wyszyńskiego, Warszawa 2000, s. 57-101.

Baranowski I., Pamiętniki (1840-1860), Poznań 1923.

Barańska A., Kobiety w powstaniu listopadowym 1830-1831, Lublin 1998.

Bender R., Działalność społeczna polskich kapucynów w XIX i XX wieku, [w:] Trzysta lat kapucynów w Polsce 1681-1981. Materiały z Sympozjum w Zakroczymiu 27-29 październik 1981, Zakroczym-Warszawa-Kraków 1987, s. 246-252.

Brzozowski M., Działalność kaznodziejsko-misyjna kapucynów, [w:] Trzysta lat kapucynów w Polsce 1681-1981. Materiały z Sympozjum w Zakroczymiu 2729 październik 1981, Zakroczym-Warszawa-Kraków 1987, s. 227-234.

Budziarek M., Kapucyni w Lublinie. Dzieje klasztoru w latach 1721-1864, Warszawa-Lublin 1996.

Ciereszko M., Kobieta oddana Bogu - obraz zakonnicy w polskiej prozie narracyjnej II połowy XIX wieku, „Prace Literaturoznawcze” 3(2015), s. 209-222.

Cygan M. J, Beniamin Szymański, kapucyn, biskup podlaski, „Szkice Podlaskie” 5(1996), s. 110-119.

Czermińska L., Duchowość Sióstr Franciszkanek od Cierpiacych. Studium na podstawie dokumentów Zgromadzenia, Łódź 2009.

Dragan P., Piotr Pawet Beniamin Szymański biskup podlaski w świetle własnych listów pasterskich, „Wiadomości Diecezji Podlaskiej” (1931) nr. 10-12, s. $415-430$.

Duchniewski J. F., Z dziejów polskiej Prowincji kapucynów (1810-1921), [w:] $W$ stużbie pokoju $i$ dobra. Jubileusz pięćdziesięciolecia odrodzenia Warszawskiej Prowincji Kapucynów. Księga Pamiątkowa, pr. zbr. pod red. R. Prejs, Warszawa 2002, s. 25-67.

Duchniewski F., Polska Prowincja Kapucynów w XIX wieku (1795-1864), [w:] Zakony franciszkańskie w Polsce, pod red J. Kłoczowskiego, t. 4, cz. 1, Lublin 1987, s. 5-209.

Falkowska J., Przeciw marzycielstwu. Działalność edukacyjna Anastazji z Jełowickich Dzieduszyckiej, Torun 2014.

Fręchowicz T., Cerkiew greko-katolicka na terenie diecezji podlaskiej za rządów biskupa Beniamina Szymańskiego, Rzym 1981. 
Gawlik S., Dziedzictwo pedagogiczne Klementyny z Tańskich Hoffmanowej, Opole 1996.

Gruszczyńska K., Historia Zgromadzenia Sióstr Franciszkanek od Cierpiacych (1905-1923), mps, [w:] Archiwum Franciszkanek od Cierpiących, C.I, T. I/27. Historia Zgromadzenia Sióstr Felicjanek na podstawie rękopisów, cz. 1, Milwaukee 1924.

Hoffman B. K., Wielki Tydzień Polaków czyli opis pamiętnych wypadków $w$ Warszawie od dnia 29 listopada do 5 grudnia 1830, Warszawa 1915. Jabłońska-Deptuła E., Niepokalanki w polskim trwaniu, Niepokalanów 1993. Jabłońska-Deptuła E., Zaangażowanie patriotyczne kapucynów, [w:] Trzysta lat kapucynów w Polsce 1681-1981. Materiały z Sympozjum w Zakroczymiu 27-29 październik 1981, Zakroczym-Warszawa-Kraków 1987, s. 235-245.

Jabłońska-Deptuła E., Trwanie $i$ budowa. Honorat Koźmiński, kapucyn (1829-1916), Warszawa 1986.

Jabłońska-Deptuła E., Gawrysiakowa J., Materiały do zaangażowania patriotycznego zakonów męskich w Królestwie Polskim w latach 1861-1864, [w:] Materiaty do historii zgromadzeń zakonnych na ziemiach polskich w XIX i na początku XX wieku, red. H. Dylągowa [i in.], Lublin 1976, s. $51-200$.

Jabłońska-Deptuła E., Przystosowanie i opór: Zakony męskie w Królestwie Kongresowym, Warszawa 1983.

Jabłońska-Deptuła E., Z problematyki ideologii i życia religijnego, „Roczniki Humanistyczne" 2(1980), s. 29-78.

Jabłońska-Deptuła E., Życie religijne w powstaniu listopadowym, „Novum” 1978, nr. 5, s. 70-105; nr. 6, s. 74-101.

Kapuścińska A., „Boska teoria socjalna, na której postęp ludzkości zawisł”. Prokop Leszczyński (1812-1895) i literacki projekt kordialno-ultramontański, Poznań 2015.

Kapuścińska A., Recepcja Skargowskiej metody parenetycznej w polskim żywotopisarstwie XIX wieku Prokopa Leszczyńskiego OFMCap (1812-1895) i ultramontańskie źródta „renesansu” hagiografii potrydenckiej, „Acta Universitatis Lodziensis. Folia Literaria Polonica" 3(21)2013, s. 317-344.

Kicka N., Pamiętniki, wstęp i przypisy J. Dutkiewicz, oprac. tekstu T. Szafrański, Warszawa 1972.

Kiniewicz S., Warszawa w powstaniu styczniowym, Warszawa 1983.

Kiniewicz S., Warszawa w latach 1795-1914, Warszawa 1976.

Klementyna z Tańskich Hoffmanowa, Pamiatka po dobrej matce czyli ostatnia jej rada dla córki. Przez młoda Polkę, Warszawa 1819.

„Kłosy” (1875), nr 509.

Komar J., Warszawskie manifestacje patriotyczne 1860-1861, Warszawa 1970. 
Koźmiński H. Wiadomości o zgromadzeniach prowadzacych życie ukryte przed światem, [w:] Wybór pism o. Honorata Koźmińskiego, cz. 5, Polskie teksty ascetyczne, t. XI, cz. 5, Warszawa 1988, s. 9-78.

Koźmiński H., Do Kardynała Dominika Ferrata, 20 II 1907 r., w: Pisma, t. 1, red. H.I. Szumił przy współpracy G. Bartoszewskiego, Warszawa 1997.

Koźmiński H., Ojciec Prokop Kapucyn, Warszawa 1895.

Kratochwil Z., Szumił I. H., Kapucyni w świetle pamiętnika Marii z Łubieńskich Górskiej, Warszawa 2001.

Kraushar A., Generałowa Sowińska i Klementyna Hoffmanowa w czasach powstania listopadowego $i$ po kapitulacji Warszawy. Karta z dziejów „Związku patriotycznego dobroczynności pań polskich” w latach 1831-1833, Lwów 1917.

Księga SS. nowicjuszek i profesek 3-go Zakonu S. O. Franciszka Kapucynek Warszawskich 1830-1857, [w:] Archiwum Główne Zgromadzenia Felicjanek, k. 1-6.

Lemańska K., Fenomen ukrytego życia zakonnego na przykładzie zgromadzeń założonych przez o. Honorata Koźmińskiego, Lublin 1995.

Leszczyński P., Mowa pośmiertna na cześć Ludwiki Diannot, Warszawa 1853.

Litwiński P., Ojciec Honorat z Białej, kapucyn, ze słowem wstępnym J. E. ks. Stanisława Galla, cz. 1, Warszawa 1938.

Markiewiczowa H., Rodzina i jej wplyw na religijne postawy dzieci w literaturze pedagogicznej: próba zarysu historii, „Studia Theologica Varsaviensia” 1(2000), s. 201-215.

Mazan-Jakubowska M., Kobiety i katolicka kultura religijna $w$ środowisku polskich ziemian i drobnej szlachty na Ziemiach Zabranych $w$ XIX wieku, „Studia Białorutenistyczne” 8(2014), s. 47-57.

Mazur E., Dobroczynność w Warszawie XIX wieku, Warszawa 1999.

Mazurek H. M., Powstanie i rozwój ukrytych zgromadzeń bt. Honorata Koźmińskiego w latach 1874-1908, oprac. i przygot. do druku H. I. Szumił, Sandomierz 2009.

Muśnicka E., O. Honorat z Białej Kapucyn, 1829-1916, Jego żywot i działalność, t. 1, Kraków 1925.

Nalepa J., „Przytulisko” warszawskie w latach 1858-1920, mps, Biblioteka Katolickiego Uniwersytetu Lubelskiego, 1967.

Odziemkowski J., Patriota, [w:] Boży człowiek w stużbie ludziom. Bt. Honorat Koźmiński, red. A. Derdziuk, G. Filipiuk, Lublin 2018, s. 113-124.

Olszewski D., Postawy społeczno-religijne kobiet $w$ Królestwie Polskim $w$ drugiej polowie XIX wieku, [w:] Kobieta i kultura religijna. Specyficzne cechy religijności kobiet w Polsce, red. J. Hoff, Rzeszów 2006, s. 11-22.

Pawelec L., Stanistaw Jachowicz (1796-1857), „Nauczyciel i Szkoła” 3-4(2003), s. 320-331. 
Prejs R., Kapucyni Prowincji Polskiej w rewolucji moralnej i powstaniu styczniowym, [w:] Życie zakonne w Królestwie Polskim w latach 1832-1864, red. W. Graczyk, J. M. Marszalska, Kraków 2015, s. 119-138.

Ricciardi A., Franciszka Siedliska. Matka Maria od Pana Jezusa Dobrego Pasterza. Założycielka Zgromadzenia Sióstr Najśw. Rodziny z Nazaretu, tłum. M. Immolata Krajewska, Władysława Minkiewicz, Rzym 1987.

Skorodziuk J., Janów Podlaski - rezydencja biskupów, „Szkice Podlaski” 13(2005), s. 11-28.

Sprawozdanie z I kapituly tercjarskiej z 3 I 1859, Akta kapituł i wyborów 1859-1864, k. 21, [w:] Archiwum Główne Zgromadzenia Felicjanek w Krakowie.

Stankiewicz-Kopeć M., Poglady Klementyny z Tańskich Hoffmanowej 17981845 w refleksji uczennic. Zarys zagadnienia, „Studia Pedagogica Ignatiana” 3(2016), s. 99-121.

Truszkowska A. M., Listy do o. Honorata Koźmińskiego, [w:] Wybór pism, t. II, cz. 1, Rzym 1980.

Werner M., O. Honorat Koźmiński. Kapucyn 1829-1916, Poznań-Warszawa 1972. Wilkońska P., Wspomnienia o życiu towarzyskim w Warszawie, Warszawa 1959.

Wójcik M., Zgromadzenie Sióstr Stużek NMP Niepokalanej. Powstanie, rozwój i działalność w latach 1878-1918, Poznań 1978.

Ziółek J., Patriotyczna postawa duchowieństwa w czasie powstania 18301831 roku, „Roczniki Humanistyczne 2(1980), s. 79-103.

Życiorys śp. Kazimiery Gruszczyńskiej, Założycielki i dlugoletniej Prezeski „Towarzystwa Pielęnowania Chorych Świętego Józefa - Przytulisko" w Warszawie, C. I, T. II/91, mps, [w:] Archiwum Franciszkanek od Cierpiących. 


\title{
ANDRZEJ BARAN OFMCap
}

\section{ODDZIALYWANIE KAPUCYNÓW WARSZAWSKICH NA KOBIETY W DOBIE MIĘDZYPOWSTANIOWEJ (1831-1864)}

Streszczenie: Przedmiotem analizy jest animacja kobiet w ramach duszpasterstwa prowadzonego przez kapucynów w okresie między powstaniem listopadowym styczniowym. Oddziaływanie ukazane jest przez pryzmat wydarzeń społeczno-politycznych. Tło wywodu stanowi różnorodność form zaangażowania kobiet $\mathrm{w}$ okresie międzypowstaniowym. Artykuł łączy ogólną perspektywę wydarzeń społeczno-politycznych z szczegółowymi formami organizowania kobiet w różne organizacje religijnokościelne z mocnym akcentem na formację patriotyczną kobiet polskich. Tematem artykułu jest też zaangażowanie kapucynów w pracę duszpasterską wśród kobiet i aktywność polityczną w połowie XIX wieku.

Słowa kluczowe: o. Beniamin Szymański, Klamentyna z Tańskich Hoffmanowa, Natalia Kicka, tercjarstwo franciszkańskie, „Przytulisko”, Związek Dobroczynności Patriotycznej, Żywy Różaniec.

\section{THE INFLUENCE OF WARSAW CAPUCHINS ON WOMEN IN THE INTER-UPRISING PERIOD (1831-1864)}

\begin{abstract}
The subject of the analysis is the animation of women under the pastoral care of the Capuchins during the period between the November and January Uprisings. The influence is presented through the prism of social and political events. The background of the argument is the diversity of forms of engagement of women in the inter-uprising period. The article combines the general perspective of socio-political events with detailed forms of organizing women in various religious and church organizations with a strong emphasis on the patriotic formation of Polish women. It reflects on the commitment of the Capuchins, their pastoral work among women and political activity in the mid- $9^{\text {th }}$ century.
\end{abstract}

Keywords: Fr. Beniamin Szymański, Klementyna Tańska Hoffmanowa, Natalia Kicka, Franciscan Third Order, "the Shelter", Union of Patriotic Charity, the Living Rosary. 